\title{
Molecular phylogeny of Acer monspessulanum L. subspecies from Iran inferred using the ITS region of nuclear ribosomal DNA
}

\author{
HANIF KHADEMI ${ }^{1}$, IRAJ MEHREGAN ${ }^{1, \boldsymbol{v}}$, MOSTAFA ASSADI ${ }^{2}$, TAHER NEJADSATARI ${ }^{1}$, \\ SHAHIN ZARRE ${ }^{3}$ \\ ${ }^{1}$ Department of Biology, Science and Research Branch, Islamic Azad University, Hesarak-1477893855, Tehran. Iran, `email: iraj@ daad-alumni.de \\ ${ }^{2}$ Research Institute of Forest and Rangelands, National Botanical Garden of Iran, P.O. Box 13185-116, Tehran, Iran \\ ${ }^{3}$ Department of Plant Sciences, School of Biology, College of Science, University of Tehran, P.O. Box 14155-6455, Tehran, Iran
}

Manuscript received: 29 September 2015. Revision accepted: 16 November 2015.

\begin{abstract}
Khademi H, Mehregan I, Assadi M, Nejadsatari T, Zarre S. 2015. Molecular phylogeny of Acer monspessulanum L. subspecies from Iran inferred using the ITS region of nuclear ribosomal DNA. Biodiversitas 17: 16-23. This study was carried out on the Acer monspessulanum complex growing wild in Iran. Internal transcribed spacer (ITS) sequences for 75 samples representing five different subspecies of Acer monspessulanum were analyzed. Beside this, 86 previously published ITS sequences from GenBank were used to test the monophyly of the complex worldwide. Phylogenetic analyses were conducted using Bayesian inference and maximum parsimony. The results indicate that most samples of $A$. monspessulanum species from Iran were part of a monophyletic clade with 8 samples of $A$. ibericum from Georgia, A. hyrcanum from Iran and one of $A$. sempervirens from Greece $(\mathrm{PP}=1 ; \mathrm{BS}=79 \%)$. Our results indicate that use of morphological characteristics coupled with molecular data will be most effective.
\end{abstract}

Keywords: Biogeography, maple, phylogeny, Sapindaceae

\section{INTRODUCTION}

The genus Acer L. is a member of Sapindaceae that mainly grows in tropical and subtropical regions. This genus is one of the most diverse tree genera in the Northern Hemisphere with approximately 129 species and is the largest tree genus of the northern hemisphere besides Quercus (Fang 1966; Grimm et al. 2006). A number of characteristics are shared among all members of Acer. The arrangement of the two winged pericarps (samaras) in the fruits ranges from subparallel to diverging at about a right angle.

A number of characters that are beneficial for identification of species in the field may have evolved independently (lobe shape, margin of lobes). These traits may be highly variable within species like pubescence of lower leaf surface (Grimm et al. 2007). Several different florescence types, including racemes, panicles, corymbs and spikes, occur in this genus. These variations make infrageneric divisions very difficult. Species delimitation and phylogenic relationships within the genus Acer are also very controversial (Kholie 1967; Judd et al. 2002). Fang (1966) proposed a different system in which the genus was divided into two subgenera, mainly on the basis of simple versus compound leaves (Koidzumi 1911). In Ogata's system (Ogata 1967), the genus was classified into 26 sections (Momotani 1962). In 1970, Murray published his monograph of the Aceraceae with 7 subgenera, 24 sections and 35 series within Acer (Murray 1970). Ogata's system was essentially followed by $\mathrm{Xu}$ (1966), with some additions and amendments. More recently de Jong (1994) recognized only 19 series in 16 sections, providing a quite different arrangement from those of other authors (Pax
1902; Xu 1966, 1998; Ogata 1967; Xu et al. 2008). Some researchers discussed the infrageneric phylogenetic relationships in the genus by analyzing gross morphology, seed proteins, fossils and geographic distributions, but the conclusions were not in consensus (Momotani 1962; Rechinger 1969; Pax 1985, 1986; Wolfe and Yanai 1987; Thorne 1992).

Acer monspessulanum is a medium-sized deciduous tree or densely branched shrub that grows to a height of 10$15 \mathrm{~m}$ (rarely to $20 \mathrm{~m}$ ) (Fontaine 2011). The trunk is up to 75 $\mathrm{cm}$ diameter, with smooth, dark grey bark on young trees, becoming finely fissured on old trees. Among similar maples is most easily distinguished by its small three-lobed leaves, 3-6 cm long and 3-7 cm wide, glossy dark green, sometimes a bit leathery, and with a smooth margin, with a $2-5 \mathrm{~cm}$ petiole. The leaves fall very late in autumn, typically in November. The flowers are produced in spring, in pendulous, yellow to white corymbs $2-3 \mathrm{~cm}$ long. The samaras are 2-3 cm long with rounded nutlets (Rushforth 1999; van Gelderen and van Gelderen 1999).

Acer monspessulanum from Acer section (van Gelderen et al. 1994) has distinct small, 3-lobed leaves, while its close relatives A. hyrcanum and A. opalus normally have 5lobed leaves. Acer ibericum displays dimorphic leaves that are 5-lobed in juvenile plants and sucker shoots, and 3lobed in older plants (Grimm et al. 2007). Acer monspessulanum fossils are fairly common in Late Miocene and Pliocene floras from southern Europe and south-western Asia (Kvacek et al. 2002; Sachse 2004).

The ITS is highly variable nuclear region suitable for phylogenetic reconstruction of closely related taxa. The utility of this marker has already been investigated in other 
plant groups including trees, e.g. Acer (Tian et al. 2002; Grimm et al. 2006; Grimm et al. 2007) and Crataegus (Zarrei et al. 2014, 2015) and bulbs (Zarrei et al. 2009).

The aim of this study is to clarify taxonomy and to delimit Acer monspessulanum subspecies that grow in Iran using ITS marker and comparing results with morphological traits.

\section{MATERIALS AND METHODS}

\section{Plant samples}

The ITS sequencing was performed on 75 individuals from 15 populations of Acer monspessulanum distributed in Iran. Population name, localities, altitude, and herbarium number for each population are shown in Table 1. The plant specimens were identified in the Department of Biology, Science and Research Branch of Islamic Azad University in Tehran, by the aid of local and regional Floras, and voucher specimens of the plants with numbers 14821-14835 were deposited in the IAUH (Table 1). The specimens were collected during July and December 2014.
Wherever possible, five trees from at least $50 \mathrm{~m}$ distant from each other were sampled randomly from each population. Fresh leaves were collected and kept in $50 \mathrm{CC}$ falcon tubes, filled with Silica Gel, for the purpose of drying them (Chase and Hill 1991). The leaves were then used as a DNA extraction source.

\section{DNA extractions and ITS amplification}

Total DNA was extracted following a modified CTAB protocol of Doyle and Doyle (1990) using the DNeasy Plant Mini kit (Qiagen, Germany). We amplified the Internal Transcribed Spacer region (ITS1-5.8S-ITS2) of the nuclear ribosomal DNA using primer combinations $18 \mathrm{~S}$ (forward primer 5'-CCT TMT CAT YTA GAG GAA GGA G-3') and 28S (reverse primer 5'-CCG CTT ATT KAT ATG CTT AAA-3'). The PCR protocol for ITS region included: 34 cycles of 18 seconds denaturation $\left(94^{\circ} \mathrm{C}\right), 30$ seconds annealing $\left(53^{\circ} \mathrm{C}\right)$, and 60 seconds elongation $\left(72^{\circ}\right.$ $\mathrm{C}$ ), with two additional minutes elongation (Gaskin and Schaal 2003). The quality of PCR products was checked by electrophoresis on a $1.0 \%$ agarose gel and then visualized under UV light.

Table 1. List of Acer monspessulanum subspecies investigated in our analysis and their morphological characters and locality in Iran (small $=$ up to $2 \times 2 \mathrm{~cm}$, large $=2-3 \times 3.5-4 \mathrm{~cm})$

\begin{tabular}{|c|c|c|}
\hline Taxon & $\begin{array}{l}\text { Locality with herbarium numbers and } \\
\text { GenBank accession numbers }\end{array}$ & $\begin{array}{l}\text { Major features of } \\
\text { morphological traits (Rechinger } \\
\text { 1969) }\end{array}$ \\
\hline $\begin{array}{l}\text { A. monspessulanum ssp. } \\
\text { turcomanicum (Pojark.) Rech. } \\
\text { f. }\end{array}$ & $\begin{array}{l}\text { Iran: Khorasan Shomali, } 45 \mathrm{~km} \text { N of Shirvan, Golul-Sarani, } \\
2302 \mathrm{~m} \text {, Basiri } 14823 \text { (IAUH) }\end{array}$ & $\begin{array}{l}\text { Leaves: large } \\
\text { Loculus inside: hairy } \\
\text { Loculus outside: sparsely hairy }\end{array}$ \\
\hline $\begin{array}{l}\text { A. monspessulanum ssp. } \\
\text { ibericum (M.B.) Yaltirik } \\
\text { A. monspessulanum } \mathrm{ssp} \text {. } \\
\text { ibericum (M.B.) Yaltirik } \\
\text { A. monspessulanum } \mathrm{ssp} \text {. } \\
\text { Ibericum (M.B.) Yaltirik } \\
\text { A. monspessulanum } \mathrm{ssp} \text {. } \\
\text { ibericum (M.B.) Yaltirik }\end{array}$ & $\begin{array}{l}\text { Iran: Azarbayejan Sharghi, Kaleybar, Arasbaran forest, Venigh, } \\
1070 \text { m, Masoud, } 14821 \text { (IAUH), KT587662 } \\
\text { Iran: Azarbayejansharghi, Kaleybar, Arasbaran forest, Tuali, } 850 \\
\text { m, Masoud, } 14822 \text { (IAUH), KT587663 } \\
\text { Iran: Golestan, Gorgan, Golestan National Park, } 677 \text { m, } \\
\text { Khademi, 14833 (IAUH), KT587665 } \\
\text { Iran: Mazandaran, Amol, Haraz road, Chelav, } 737 \text { m, Khademi, } \\
\text { 14834 (IAUH), KT587661 }\end{array}$ & $\begin{array}{l}\text { Leaves: large } \\
\text { Loculus inside: hairy } \\
\text { Loculus outside: glabrous } \\
\text { Lower surface midrib: glabrous }\end{array}$ \\
\hline $\begin{array}{l}\text { A. monspessulanum ssp. } \\
\text { assyriacum (Pojark.) Rech. } \\
\text { A. monspessulanum ssp. } \\
\text { assyriacum (Pojark.) Rech. } \\
\text { A. monspessulanum ssp. } \\
\text { assyriacum (Pojark.) Rech. }\end{array}$ & $\begin{array}{l}\text { Iran: Kordestan, Mariwan, Mohhamadeh village toward } \\
\text { Benavechele, } 1550 \text { m, Khademi, } 14828 \text { (IAUH), KT587655 } \\
\text { Iran: Kordestan, Mariwan, Mohhamadeh village toward } \\
\text { Benavechele, } 1510 \text { m, Khademi, } 14829 \text { (IAUH), KT587653 } \\
\text { Iran: Kermanshah, Jawanroud toward Salas, } 1585 \text { m, Khademi, } \\
\text { 14832 (IAUH), KT587654 }\end{array}$ & $\begin{array}{l}\text { Leaves: large } \\
\text { Loculus inside: hairy } \\
\text { Loculus outside: glabrous } \\
\text { Lower surface midrib: sparsely } \\
\text { hairy }\end{array}$ \\
\hline $\begin{array}{l}\text { A. monspessulanum ssp. } \\
\text { cinerascens (Boiss.) Yaltirik } \\
\text { A. monspessulanum ssp. } \\
\text { cinerascens (Boiss.) Yaltirik } \\
\text { A. monspessulanum ssp. } \\
\text { cinerascens (Boiss.) Yaltirik } \\
\text { A. monspessulanum ssp. } \\
\text { cinerascens (Boiss.) Yaltirik } \\
\text { A. monspessulanum ssp. } \\
\text { cinerascens (Boiss.) Yaltirik }\end{array}$ & $\begin{array}{l}\text { Iran: Fars, Marwdasht, Jahanabad village, } 1756 \text { m, Khademi, } \\
14824 \text { (IAUH), KT587656 } \\
\text { Iran: Fars, Marwdasht, Bizjan village, Dorodzan Dam, } 1715 \text { m, } \\
\text { Khademi, } 14825 \text { (IAUH), KT587657 } \\
\text { Iran: Fars, Marwdasht, Chav road, } 1823 \text { m, Khademi, } 14826 \\
\text { (IAUH). KT587658 } \\
\text { Iran: Fars, Bayza. Tang Tir forest, } 1632 \text { m, Khademi, } 14827 \\
\text { (IAUH), KT587659 } \\
\text { Iran: Kohgiloye-va-Boir Ahmad, Gachsaran, Gachsaran, } 15 \text { km } \\
\text { to Choram, After Abrigoon, Deel neck, } 1600 \text { m, Mehrgan, } 14835 \\
\text { (IAUH) }\end{array}$ & $\begin{array}{l}\text { Leaves: small } \\
\text { Loculus inside: densely hairy } \\
\text { Loculus outside: glabrous }\end{array}$ \\
\hline $\begin{array}{l}\text { A. monspessulanum ssp. } \\
\text { persicum (Pojark.) Rech. } \\
\text { A. monspessulanum ssp. } \\
\text { persicum (Pojark.) Rech. }\end{array}$ & $\begin{array}{l}\text { Iran: Kerman, } 25 \mathrm{~km} \text { from Dalfard toward Jiroft, } 980 \text { m, } \\
\text { Meyjani, } 14830 \text { (IAUH) } \\
\text { Iran: Kerman, Meyjan, } 1218 \text { m, Meyjani, } 14831 \text { (IAUH), } \\
\text { KT587664 }\end{array}$ & $\begin{array}{l}\text { Leaves: small } \\
\text { Loculus inside: glabrous } \\
\text { Loculus outside: sparsely hairy }\end{array}$ \\
\hline
\end{tabular}


Table 2. List of taxa used in our analysis with their GenBank accession numbers.

\begin{tabular}{ccc}
\hline Taxon & Region & $\begin{array}{l}\text { GenBank } \\
\text { accession } \\
\text { numbers }\end{array}$ \\
\hline
\end{tabular}

A. hyrcanum ssp. hyrcanum

A. hyrcanum ssp. hyrcanum

A. hyrcanum ssp. hyrcanum

A. hyrcanum ssp. hyrcanum

A. ibericum

A. ibericum

A. ibericum

A. ibericum

A. ibericum

A. ibericum

A. ibericum

A. ibericum

A. ibericum

A. ibericum

A. ibericum

A. monspessulanum

A. monspessulanum

A. monspessulanum

A. monspessulanum

A. monspessulanum

A. monspessulanum

A. monspessulanum

A. monspessulanum

A. monspessulanum

A. monspessulanum

A. monspessulanum

A. monspessulanum

A. monspessulanum

A. monspessulanum

A. monspessulanum ssp. monspessulanum France AM238355

A. monspessulanum ssp. monspessulanum France AM238357

A. monspessulanum ssp. monspessulanum France AM238358

A. monspessulanum ssp. monspessulanum France AM238359

A. monspessulanum ssp. monspessulanum France AM238361

A. monspessulanum ssp. monspessulanum France AM238362

A. monspessulanum ssp. monspessulanum France AM238363

A. monspessulanum ssp. monspessulanum France AM238364

A. monspessulanum ssp. monspessulanum France AM238365

A. monspessulanum ssp. monspessulanum France AM238366

A. monspessulanum ssp. monspessulanum France

A. monspessulanum ssp. monspessulanum France

A. monspessulanum ssp. monspessulanum France

A. monspessulanum ssp. monspessulanum France

A. monspessulanum ssp. monspessulanum France

A. monspessulanum ssp. monspessulanum France

A. monspessulanum ssp. monspessulanum Spain

A. monspessulanum ssp. monspessulanum Spain

A. monspessulanum ssp. monspessulanum Spain

A. monspessulanum ssp. monspessulanum France

A. monspessulanum ssp. monspessulanum France

A. monspessulanum ssp. monspessulanum France

A. monspessulanum ssp. monspessulanum France

A. monspessulanum ssp. monspessulanum France

A. monspessulanum ssp. monspessulanum France

A. monspessulanum ssp. monspessulanum France
AM238367

AM238368

AM238369

AM238370

AM238371

AM238373

AM238374

AM238375

AM238376

AM238377

AM238378

AM238379

AM238380

AM238381

AM238382

AM238383
A. monspessulanum ssp. monspessulanum France

A. monspessulanum ssp. monspessulanum France

A. monspessulanum ssp. monspessulanum France

A. monspessulanum ssp. monspessulanum France

A. monspessulanum ssp. monspessulanum France

A. monspessulanum ssp. monspessulanum France

A. monspessulanum ssp. monspessulanum France

A. monspessulanum ssp. monspessulanum France

A. monspessulanum ssp. monspessulanum France

A. monspessulanum ssp. monspessulanum France

A. monspessulanum ssp. monspessulanum France

A. monspessulanum ssp. monspessulanum France

A. monspessulanum ssp. monspessulanum France

A. monspessulanum ssp. monspessulanum Germany AM

AM238401

A. monspessulanum ssp. monspessulanum Germany AM238402

A. monspessulanum ssp. monspessulanum Spain AY605315

A. monspessulanum ssp. monspessulanum Spain AY605316

A. monspessulanum ssp. monspessulanum Spain AY605317

A. monspessulanum ssp. monspessulanum France AY605318

A. monspessulanum ssp. monspessulanum France AY605319

A. monspessulanum ssp. monspessulanum France AY605320

A. monspessulanum ssp. monspessulanum France AY605321

A. monspessulanum ssp. monspessulanum France DQ366124

A. monspessulanum ssp. monspessulanum France DQ366125

A. monspessulanum ssp. monspessulanum France DQ366126

A. monspessulanum ssp. monspessulanum France DQ366127

A. monspessulanum ssp. monspessulanum France DQ366128

A. obtusifolium

A. obtusifolium

A. obtusifolium

A. obtusifolium

A. obtusifolium

A. obtusifolium

A. opalus

A. opalus

A. opalus

A. opalus

A. opalus

A. opalus

A. sempervirens

A. sempervirens

A. sempervirens

A. sempervirens

A. sempervirens

A. sempervirens

A. sempervirens

A. sempervirens

A. sempervirens

A. sempervirens

A. sempervirens

A. sempervirens

A. sempervirens

A. sempervirens

A. sempervirens

A. sempervirens

A. sempervirens

A. sempervirens

A. sempervirens

A. sempervirens

A. velutinum

Note: ssp. $=$ subsp. $=$ sub species
Cyprus AM238327

Cyprus AM238328

Cyprus AM238329

Cyprus AM238330

Syria AM238331

Syria AM238332

France AM238418

France AM238419

France AM238420

France AM238421

France AM238422

Greece AM238334

Greece AM238335

Greece AM238336

Greece AM238337

Greece AM238340

Greece AM238341

Greece AM238342

Greece AM238343

Greece AM238344

Greece AM238348

Greece AM238349

Greece AM238350

Greece AM238351

Greece AY605349

Greece AY605350

Greece AY605351

Greece AY605352

Greece AY605353

Greece DQ366122

Greece DQ366123

Iran AY605361
France AM238417 


\section{Phylogenetic analyses}

Phylogenetic reconstructions were performed with 15 samples from each of 75 accessions (15 populations) belonging to five subspecies of Acer monspessulanum from Iran (Table 1). In addition, we used the ITS sequence of 86 accessions of Acer from GenBank. List of non-Iranian taxa used in our analysis with GenBank accession numbers are shown in Table 2. We used ITS sequences of Acer velutinum Boiss. from GenBank as the outgroup based on the earlier studies including Grimm et al. (2006) (Table 2).

The 3 ' region of the $18 \mathrm{~S}$ rDNA, the 5 ' region of the $26 \mathrm{~S}$ rDNA, and the whole ITS1-5.8S rDNA-ITS2 region were sequenced for all the taxa, and these were compared to sequences produced for other maples. Forward and reverse sequences were visually compared and edited, and then aligned using Sequencher 4 software (Gene Codes Corporation, Ann Arbor, MI, USA). In addition to our sequences, 86 ITS sequences from other taxa were taken from GenBank (Table 2). All ITS sequences were assembled and aligned using MacClade 4 (Maddison and Maddison 2005). The parsimony analyses were performed using PAUP*4.0b10 (Swofford 2002), with the following options: heuristic search with 1,000 random-additionsequence replicates; tree bisection-reconnection (TBR) branch swapping; saving all most parsimonious trees. Character state changes were treated as equally weighted. Relative clade support was estimated using 1,000 bootstrap replicates in PAUP* via full heuristic searches and simple taxon addition. Clades with a bootstrap value of $50 \%$ or more were considered as robustly supported nodes. The consistency index (CI) and retention index (RI) were calculated to assess the amount of homoplasy present in the data. The best-fitting substitution model $(\mathrm{TrN}+\mathrm{I})$ was determined under the Akaike Information Criterion (AIC; Akaike 1974) using Modeltest 3.7 (Posada and Crandall 1998). The Bayesian analysis (BA) of the ITS datasets were performed using MrBayes v3.1.2 (Huelsenbeck and Ronquist 2001). TrN+I is a transitional model with six rates. For the ITS dataset, the TrN+I model was chosen. The amount of proportion of invariable sites (I) was 0.6732 .

\section{RESULTS AND DISCUSSION}

The data set of the ITS region included 675 characters, 43 of them parsimony informative. Strict consensus tree (length of 138 steps, consistency index $(\mathrm{CI})=0.703$, retention index $(\mathrm{RI})=0.904)$ is shown in Figure 1. Figure 2 shows tree from Bayesian analysis using MrBayes. All sampled species of Iranian Acer were part of a monophyletic clade with Posterior Probability $(\mathrm{PP})=1$ and Bootstrap Support $(\mathrm{BS})=79 \%$ (Clade N; Figure 1). Since Iranian A. monspessulanum origin are from Mediterranean (Rechinger 1969), we compare other studies that have involved North Africa samples, and found that European, North Africa and Asia Minor samples are in one clade as Acer core clade with BS 75\% and PP 0.96 (Grimm et al. 2007).

Our maximum parsimony results (Figure 1) indicate that Iranian A. monspessulanum subspecies (13 populations) in clade $\mathrm{N}$ are closely related to eight $A$. ibericum samples from Georgia, one sample of $A$. hyrcanum from Iran and two samples of $A$. sempervirens from Greece $(\mathrm{pp}=1, \mathrm{BS}=$ 79). This agrees with results reported by Grimm et al. (2007) where different taxa of one of one group fall into three lineages. In their results, Acer monspessulanum and A. ibericum + A. hyrcanum group together in the graph and long proximal edges indicate that they are most closely related. Clones of A. monspessulanum are distinct and placed near the center of the graph (Grimm et al. 2007).

Clade $\mathrm{O}$ that includes six specimens of $A$. ibericum from Georgia with one specimen of A. monspessulanum subsp. turcomanicum from Iran and one specimen of $A$. sempervirens from Greece $(\mathrm{PP}=0.79 ; \mathrm{BS}=62 \%)$ has proved Rechinger results about Iranian Acer origin. Clade M comprises 4 species of $A$. monspessulanum from Bulgaria with $\mathrm{PP}=0.8$ and $\mathrm{BS}=77 \%$. Clades $\mathrm{M}$ and $\mathrm{N}$ together are in clade $\mathrm{C}(\mathrm{PP}=0.95)$. This close relation between Iranian and Bulgarian Acer monspessulanum species samples support this notion that they have an origin in Mediterranean region (Rechinger 1969). Clade L has two species from France, one A. monspessulanum and A. monspessulanum ssp. monspessulanum. Clade $\mathrm{K}$ include clade $\mathrm{L}$ with another $A$. monspessulanum ssp. monspessulanum from France ( $\mathrm{PP}=$ 0.84). Clade $\mathrm{J}$ includes clades $\mathrm{K}$ and $\mathrm{L}$ with four taxa of $A$. monspessulanum ssp. monspessulanum from France and Spain. Clade I have three A. monspessulanum ssp. monspessulanum from France with $\mathrm{PP}=0.91$. Clade $\mathrm{H}$ include 17 A. monspessulanum ssp. monspessulanum with A. opalus, all from France $(\mathrm{PP}=0.97)$. Each clades of $\mathrm{G}$ and $\mathrm{F}$ has two A. monspessulanum ssp. monspessulanum from France with $\mathrm{PP}=1$ and $\mathrm{BS}=80 \%$. Clade $\mathrm{E}$ comprise clades F, G, H, I, J, K and L from France and Spain. Clade $\mathrm{D}$ has only one species A. monspessulanum from France that with clade $\mathrm{E}$ are in clade $\mathrm{B}$ with $\mathrm{BS}=50 \%$. Clade $\mathrm{P}$ that has one A. velutinum from Iran, consider as out-group in our analysis. Data analysis indicates that the classification of species according presence or absence of hairs in inner or outer surface of loculus is a true morphological characteristic for delimitation of subspecies in Acer monspessulanum.

The observed polytomies in clades $\mathrm{E}$ and $\mathrm{N}$ indicated that these taxa are taxonomically closely related and there were not enough time passed since divergence from their ancestral taxa (Zarrei et al. 2009). More divergent markers, i.e. low-copy nuclear genes, could potentially resolve these branches.

Based on our results using Bayesian analysis, some well resolved clades were present (Figure 2). Clade A comprise two subclades, $\mathrm{E}$ and $\mathrm{F}$. Clade $\mathrm{E}$ includes four $A$. monspessulanum specimens from Bulgaria and clade $\mathrm{F}$ includes 27 taxa $(\mathrm{PP}=1)$, that 13 of them are $A$. monspessulanum subspecies from Iran and others are $A$. ibericum (from Georgia), A. sempervirens (from Greece) and $A$. hyrcanum subsp. hyrcanum (from Iran), this clade proved Mediterranean origin of Iranian Acer (clade F; Figure 2). One of our taxa (A. monspessulanum subsp. ibericum) placed in clade $\mathrm{L}$ with five $A$. ibericum from Georgia and an Acer sempervirens from Greece with high support $(\mathrm{PP}=0.79)$. This placement indicates that $A$. monspessulanum and A. sempervirens are closely related together (Grimm et al. 2007). 


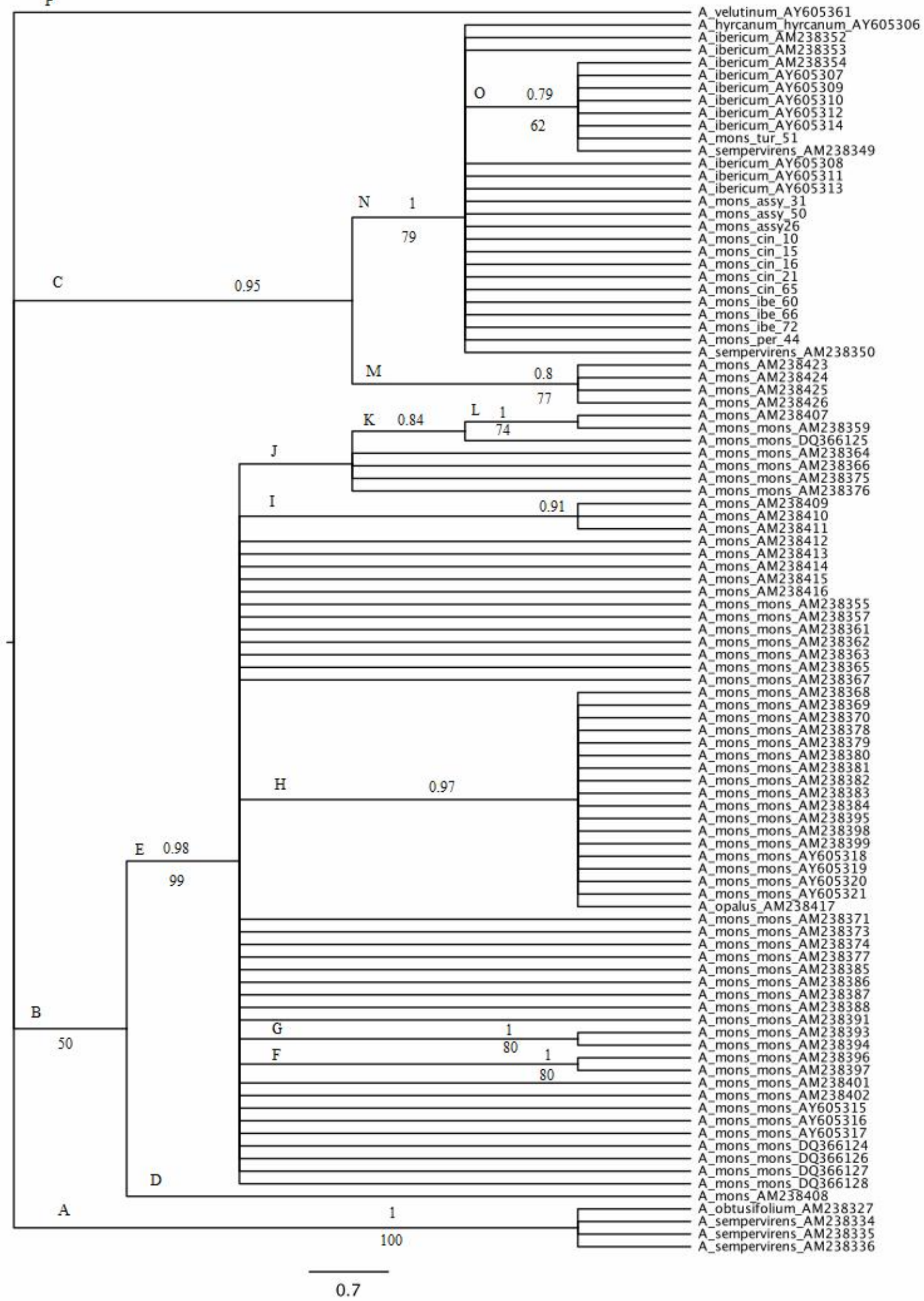

Figure 1. Phylogenetic relationships of 13 samples of Acer from Iran, on the basis of the analysis of internal transcribed spacer (ITS) sequences. Numbers above branches are Bayesian posterior probabilities. Numbers below branches are bootstrap values 


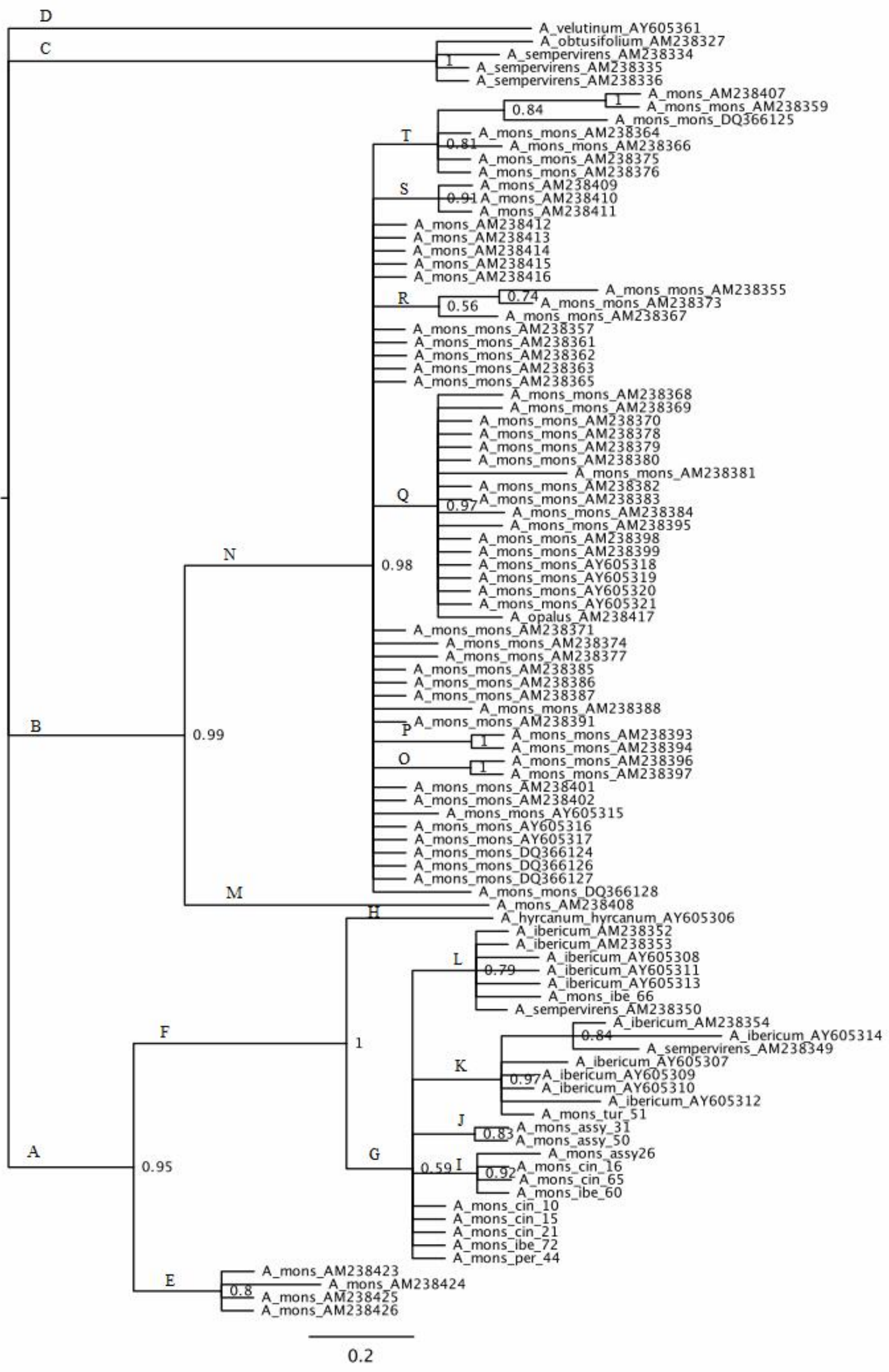

Figure 2. Bayesian tree. Numbers on nodes represent posterior probability values 
Clade B (Figure 2) have two subclades $\mathrm{M}$ and N (PP= 0.99) that include European Acer monspessulanum (from France, Spain and Germany). Clades $\mathrm{G}$ and $\mathrm{N}$ show polytomies since comprise species their morphology are closely related together.

Clade C (Figure 2) have four taxa, three of them are $A$. sempervirens from Greece and one A. obtusifolium from Cyprus $(\mathrm{PP}=1)$ that in Grimm et al. (2007) study In Europe, their distribution ranges from northern, cooltemperate latitudes (southern Sweden, A. pseudoplatanus L., naturalized) throughout central, western, and southeastern Europe (A. hyrcanum Fischer \& Meyer, A. opalus P. Miller, A. pseudoplatanus) to the subtropical Mediterranean (A. monspessulanum L., A. opalus, A. heldreichii Orphanides ex Boissier, A. sempervirens L., and A. obtusifolium Sibthorp \& Smith), and with an eastward expansion to Asia Minor, the Caucasus, and Iran $(A$ trautvetteri Medvedev, A. hyrcanum, A. ibericum Bieberstein ex Willdenow, A. monspessulanum, $A$. pseudoplatanus, and A. velutinum Boissier) (Grimm et al. 2007).

Subspecies geographical distribution show that assyriacum subspecies from Kordestan and Kermanshah provinces are near together and support with Bayesian analysis $(\mathrm{PP}=0.82)$. A. monspessulanum subsp. ibericum collected from Arasbaran forest (Azarbayejansharghi province) placed in clade L (Figure 2) with A. ibericum from Georgia $(\mathrm{PP}=0.79)$ that from geographical distribution approach is justifiable. All Iranian Acer monspessulanum in the present survey made a clade with two A. sempervirens from Greece and eleven A. ibericum from Georgia and one A. hyrcanum subsp. hyrcanum from Iran with high Bayesian support $(\mathrm{PP}=1)$.

Because ITS results couldn't delimitate on subspecies level we used from morphological traits. Some morphological features are important for identification of subspecies A. monspessulanum, such as size of the leaves, lower surface midrib hair and loculus inside and outside base on presence or absence of hair. One of the most important characteristic traits for distinguish between some subspecies of A. monspessulanum, is presence or absence of hair inside and outside their loculus. Based on the size of the leaves we have two groups, (i) small (up to $2 \times 2 \mathrm{~cm}$ ) that has two subspecies (ssp. persicum and ssp. cinarescens) and (ii) large $(2-3 \times 3.5-4 \mathrm{~cm})$ with three subspecies (ssp. turcomanicum, ssp. assyriacum and ssp. ibericum). Lower surface midrib hair separate only two subspecies of $A$. monspessulanum, one of them is glabrous (ssp. ibericum) and the other is sparsely hairy (ssp. assyriacum), so this trait is not a proper discriminative factor for other three subspecies. Loculus outside hair has two state, (i) glabrous (ssp. turcomanicum, ssp. persicum) and (ii) sparsely hairy (ssp. ibericum, ssp. assyriacum, ssp. cinarescens). We have three group base on loculus inside hair, (i) hairy (ssp. turcomanicum, ssp. ibericum, ssp. assyriacum), (ii) densely hairy (ssp. cinarescens) and (iii) glabrous (ssp. persicum) (Wolfe and Yanai 1987), so the most important and discriminative character to detect subsp. persicum from subsp. cinarescens is loculus inside hair.

The internal transcribed spacer of the nuclear region (ITS) is a widely used molecular marker for reconstruction of evolutionary patterns in plant kingdom. It has been used both in the higher taxonomic level (i.e. family) as well as lower even below the species rank (Zarrei et al. 2014). Our results indicate that this marker could be potentially valuable in delineating subspecies boundaries in maple species. The limiting factor is that this marker is not well diverged in some groups. A more divergent molecular marker such as low copy nuclear genes and intergenic nuclear spacers could potentially be helpful. Based on our experiences working on Acer and results of others studies on tree taxa (Zarrei et al. 2014); we suggest combining our ITS DNA sequences with additionally markers to increase the power of our phylogenetic analysis and improve resolution of unresolved clades. Such strategies have been applied before (see Zarrei et al. 2015). The implication of next generation sequencing data has been already proven in revolving systematic problem with closely related species (Liston et al. 2015).

\section{ACKNOWLEDGEMENTS}

This article is extracted from first author's Ph.D. thesis. We would like to thank from Islamic Azad University, Science and Research Branch, Tehran, Iran for providing the facilities necessary to carry out the work and Masoud, Basiri and Meyjani for their help in plant material collection. We thank the invaluable suggestions of an anonymous reviewer on early draft of this manuscript.

\section{REFERENCES}

Akaike H. 1974. A new look at the statistical model identification. IEEE Trans Automat Contr 19, 718-723.

APG [Angiosperm Phylogeny Group]. 1998. An ordinal classification for the families Ann Mo Bot Gard 85: 531-553.

Chase MW, Hills HG. 1991. Silica gel: an ideal desiccant for preserving field-collected leaves for use in molecular studies. Taxon 40: 215220.

De Jong PC. 1994. Taxonomy and reproductive biology of maples. Timber Press, Portland, USA.

Doyle JJ, Doyle JL. 1990. Isolation of plant DNA from fresh tissue. Focus 12: $13-15$.

Fang W. 1966. Rivisio Taxorum Aceracearum Sinicarum. Acta Phytotax Sin 11: 139-189.

Fontaine C. 2011. Fleurs De France (French Edition), Nabu Press, French.

Gaskin JF, Schaal BA. 2003. Molecular phylogenetic investigation of US invasive Tamarix. Syst Bot 28 (1): 86-95.

Grimm GW, Denk T, Hemleben V. 2007. Evolutionary history and systematics of Acer section Acer-a case study of low-level phylogenetics. Plant Systematics and Evolution. 267: 215-253.

Grimm GW, Renner SS, Stamatakis A, Hemleben V. 2006. A Nuclear Ribosomal DNA Phylogeny of Acer Inferred with Maximum Likelihood, Splits Graphs, and Motif Analysis of 606 sequeces. Evol Bioinform 2: 7-22.

Huelsenbeck JP, Ronquist F. 2001. MrBayes: Bayesian inference of phylogeny. Bioinformatics 17: 754-755.

Judd WS, Campbell CS, Kellogg EA, Donoghue MJ. 2002. Plant Systematics: A Phylogenetic Approach, 2nd ed. Sinauer Associates, Sunderland, MA. 
Kholie DK. 1967. Les chênes de. L’Iran. [Ph.D. Dissertation]. Universite de Montpellier, Montpellier, France [France]

Koidzumi G. 1911. Revisio Averacearum Japonicarum. J Coll Sci Imp Univ Tokyo 32: 1-75.

Kvacek Z, Velitzelos D, Velitzelos E. 2002 Late Miocene Flora of Vegora, Macedonia, N Greece. Korali, Athens.

Liston A, Weitemier K, Kronmiller B, Zarrei M, Dickinson T. 2015 Using Hyb-Seq data to test phylogenetic hypotheses in hawthorn (Crataegus, Rosaceae). Botany 2015, Botanical Society of America. Edmonton, AB.

Maddison DR, Maddison WP. 2005. MacClade 4: Analysis of phylogeny and character evolution. Version 4. http://macclade.org.

Momotani Y. 1962. Taxonomic study of the genus Acer, with special refrence to the seed protein. Mem Coll Sci Uni Kyoto Ser. B. (29): 177-189.

Murray E. 1970. A monograph of the Acer. Pennsylvania Pennsylvania State University.

Ogata K. 1967. A systematic Study of the genus Acer. Bull Tokyo Univ Forest. 63: 89-206.

Pax F. 1902. Aceraceae. Engler's Pflanzenreich IV. 163: 1-89.

Pax F. 1985. Monogeraphic der Gattung Acer. Bot Jahrb Engler. 6: 287373.

Pax F. 1986. Monogeraphic der Gattung Acer. Bot Jahrb Engler. 7: 177263.

Posada D, Crandall KA. 1998. Modeltest: testing the model of DNA substitution. Bioinformatics 14 (9): 817-818.

Rechinger KH. 1969. Flora Iranica, Aceraceae. Vol 61. Graza, Austria: Akademische Druck-u. Verlagasanstalt.

Rushforth KD. 1999. Trees of Britain and Europe. HarperCollins, London.

Sachse M. 2004. Die Neogene Mega-und Mikro-flora von Makrilia auf Kreta und ihre Aussagen zur Klima-und Vegetationsgeschichte des o“stlichen Mittelmeergebietes. Flora Tertiaria Mediterranea 6: 1-323.
Swofford DL. 2002. Phylogenetic analysis using parsimony (PAUP). Ver. 4. Sinauer Associated Sunderland, MA.

Thorne R. 1992. An updated phylogenetic classification of the flowering plants. Aliso 13: 365-389.

Tian X, Guo ZH, Li DZ. 2002. Phylogeny of Aceraceae Based on ITS and trn L-F Data Sets. Acta Botanica Sinica 44 (6): 714-724.

van Gelderen CJ, van Gelderen DM. 1999. Maples for Gardens: A Color Encyclopedia. Timber Press, Inc., Portland.

van Gelderen DM, de Jong PC, Oterdoom HJ. 1994. Maples of the World. Timber Press, Portland.

Wolfe JA, Yanai T. 1987. Systematics, Phylogeny and distribution pf Acer (Maples) in the Cenozoic of Western North America. J Fac Sci, Ser. IV. 22: 1-246.

$\mathrm{Xu}$ T, Chen Y, de Jong PC, Oterdoom HJ, Chang CS. 2008. Aceraceae.In: Flora of China. Vol. 11. Flora of China Editorial Committee. Science Press, Beijing.

Xu T. 1966. A new system of Acer. Acta Bot Yunnan 18: 277-292.

Xu T. 1998. The systematic evolution and distribution of the genus Acer. Acta Bot Yunnan 20: 383-393.

Zarrei M, Stefanović S, Dickinson TA. 2014. Reticulate evolution in North American black-fruited hawthorns (Crataegus section Douglasia; Rosaceae): evidence from nuclear ITS2 and plastid sequences. Ann Bot 114: 253-269.

Zarrei M, Talent N, Kuzmina M et al. 2015. DNA barcodes from four loci provide poor resolution of taxonomic groups in the genus Crataegus. AoB Plants 7: plv045. DOI: 10.1093/aobpla/plv045

Zarrei M, Wilkin P, Fay MF, Ingrouille MJ, Zarre S, Chase MW. 2009. Molecular systematics of Gagea and Lloydia (Liliaceae; Liliales): implications of analyses of nuclear ribosomal and plastid sequences for infrageneric classification. Ann Bot 104: 125-142. 